\title{
Once or Twice a Month
}

National Cancer Institute

\section{Source}

National Cancer Institute. Once or Twice a Month. NCI Thesaurus. Code C129568.

An indication that something is scheduled, or occurs, once or twice a month. 